\title{
Pengembangan Media Pembelajaran Berbasis Multimedia Pada Mata Pelajaran IPS Kelas V SD
}

\author{
Alfrina Mewengkang ${ }^{1}$ \\ Universitas Negeri Manado \\ e-mail: mewengkangalfrina@ unima.ac.id \\ Agustinus Takaredase $^{2}$ \\ Universitas Negeri Manado \\ Putri Y. Kale' $\mathbf{e}^{3}$ \\ Universitas Negeri Manado
}

\begin{abstract}
ABSTRAK
Tujuan dari penelitian ini adalah untuk mengembangkan pembelajaran berbasis multimedia yang efektif, kreatif dan mendukung proses penyampaian pesan dan informasi kepada peserta didik dalam proses pembelajaran. Metode pengembangan media pembelajaran keragaman budaya di Indonesia ini menggunakan metode pengembangan MDLC versi Luther-Sutopo dan untuk pengujian aplikasi ini menggunakan metode pengujian white box untuk developer test dan metode pengujian black box untuk end user test. Aplikasi ini menggunakan dasar pemograman Adobe ActionScript 3.0 pada Adobe Flash. Hasil dari penelitian ini menampilkan pilihan menu keragaman budaya di Indonesia. Kemudian sistem akan menampilkan pilihan sesuai dengan pilihan user. Sistem menampilkan pembelajaran dengan dukungan gambar, teks dan video yang menjelaskan tentang materi pembelajaran yang sedang ditampilkan.
\end{abstract}

Kata Kunci: Aplikasi, Pengembangan MDLC, Keragaman Budaya di Indonesia

\begin{abstract}
The purpose of this study is to develop multimedia-based learning that is effective, creative and supports the process of delivering messages and information to students in the learning process. This method of developing cultural diversity learning media in Indonesia uses the Luther-Sutopo MDLC development method and for testing this application uses the white box testing method for developer tests and black box testing methods for end user tests. This application uses the basic programming of Adobe ActionScript 3.0 in Adobe Flash. The results of this study show a menu of cultural diversity in Indonesia. Then the system will display options according to the user's choice. The system displays learning with the support of images, text and videos that explain the learning material being displayed.
\end{abstract}

Keywords: Applications, Development of MDLC, Cultural Diversity in Indonesia

\section{PENDAHULUAN}

Proses pembelajaran merupakan suatu kegiatan yang begitu penting, dimana terjadinya saling komunikasi antar pengajar maupun peserta didik. Dalam keefektifan suatu proses pembelajaran sangat mempengaruhi hasil yang akan dicapai, baik guru selaku pengajar dan siswa sebagai peserta didik. Menurut Oemar Hamalik (2006:239) pembelajaran adalah "suatu kombinasi yang tersusun meliputi unsur-unsur manusiawi, material fasilitas, perlengkapan dan prosedur yang saling mempengaruhi tercapainya tujuan pembelajaran". Proses pembelajaran terjadi karena adanya interaksi antar seseorang dan lingkungan sekitarnya.

Suatu perantara yang digunakan dalam pembelajaran dinamakan media. Menurut Arsyad (2011: 3), "kata media berasal dari bahasa latin medius yang 
secara harfiah berarti tengah, perantara atau pengantar. Dalam bahasa Arab media adalah perantara atau pengantar pesan dari pengirim kepada penerima pesan". Selanjutnya menurut Munir (2009: 88) menyatakan bahwa, "dalam proses pembelajaran interaktif, terjadi beberapa bentuk komunikasi, yaitu satu arah (one way communication) dan dua arah (two ways communication), dan banyak arah (multy ways communication) berlangsung antara pengajar dan siswa. Pengajar menyampaikan materi pembelajaran dan siswa memberikan tanggapan (respon) terhadap materi tersebut".

Bidang pendidikan sudah banyak terpengaruh dengan penemuanpenemuan yang mengacu pada perkembangan teknologi. Seiring dengan perkembangan zaman, kebudayaan yang ada di Indonesia pada saat ini secara perlahan tapi pasti mulai terlupakan. Banyak masyarakat terutama siswa Sekolah Dasar tidak mengetahui dan mengenal budaya nusantara yang ada di Indonesia, yang seharusnya mereka ketahui dan mereka lestarikan. Sebelumnya pengenalan budaya nusantara masih terpaku pada buku panduan, sehingga peserta didik akan merasa jenuh.

"Cultural Diversity atau yang sering disebut dengan istilah keragaman budaya merupakan keniscayaan yang ada di Indonesia. Keberadaan keragaman budaya Indonesia tidak dapat dipungkiri keberadaannya. Banyak sekali jenis perbedaan yang dimiliki bangsa Indonesia, mulai dari suku, budaya, ras agama, dan masih banyak lainnya" (Ibnu Asmara, 2018).

Kemajuan dari teknologi pembelajaran, menuntut digunakannya berbagai media pembelajaran. Pembelajaran yang dirancang dengan kreatif, memanfaatkan teknologi dalam batasan-batasan tertentu dapat merangsang minat belajar siswa yang berimbas pada peningkatan hasil belajar. Untuk itu media pembelajaran interaktif sangat perlu diimplementasikan dalam lingkungan pendidikan.

Kenyataan saat ini yang ditemui di SD Negeri Lanumor, terdapat beberapa kendala dalam proses pembelajaran, seperti penyajian materi yang masih bersifat monoton dan kurang menarik perhatian siswa. Media-media pembelajaran yang digunakan masih berupa alat peraga sederhana yang kurang menarik. Hal ini dapat memberi pandangan bahwa proses pembelajaran tersebut masih sangat lemah.

Kendala-kendala tersebut dapat mempengaruhi minat dan hasil belajar dari siswa jika media yang digunakan kurang menarik. Selain itu tingkat keberhasilan dalam penyampaian pesan dan informasi kepada siswa tidak akan terpenuhi dengan baik sehingga menyebabkan hasil belajar siswa rendah. Dalam mengatasi lemahnya proses pembelajaran, salah satu solusi yang ditawarkan adalah media pembelajaran interaktif dan menarik. Media yang dimaksud adalah media yang dapat merangsang kemampuan dan ketertarikan siswa dalam belajar pada proses pembelajaran.

\section{METODE}

Metode yang digunakan dalam pengembangan media pembelajaran ini adalah Multimedia Development Life Cycle. 


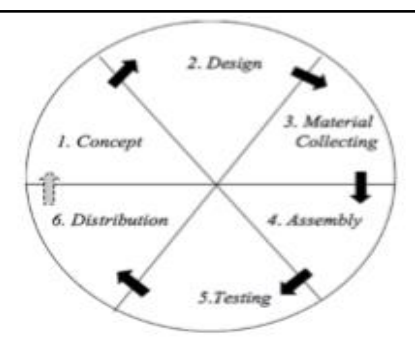

Gambar 1. Tahapan Pengembangan MDLC

Gambar 1 menunjukkan pengembangan metode multimedia ini dilakukan berdasarkan enam tahap, yaitu : concept (konsep), Design (desain), Obtaining content material/material collecting (pengumpulan materi), Assembly (Pembuatan), Testing (Pengujian) dan Distribution (Pendistribusian). Keenam tahap ini tidak harus berurutan dalam praktiknya, tahap-tahap tersebut dapat saling bertukar posisi. Meskipun begitu, tahap concept memang harus menjadi hal yang pertama kali dikerjakan, dan tahap distribution memang harus menjadi hal yang paling terakhir dikerjakan.

\section{HASIL DAN PEMBAHASAN}

Hasil yang dicapai dari penelitian ini adalah aplikasi pembelajaran berbasis multimedia pada mata pelajaran IPS kelas v SDN Lanumor Kabupaten Morowali Utara yang berisi materi keragaman budaya di Indonesia, yang terdiri dari rumah adat, pakaian adat, alat musik, tarian daerah, dan senjata tradisional. Adapun hasil dari penelitian adalah sebagai berikut:

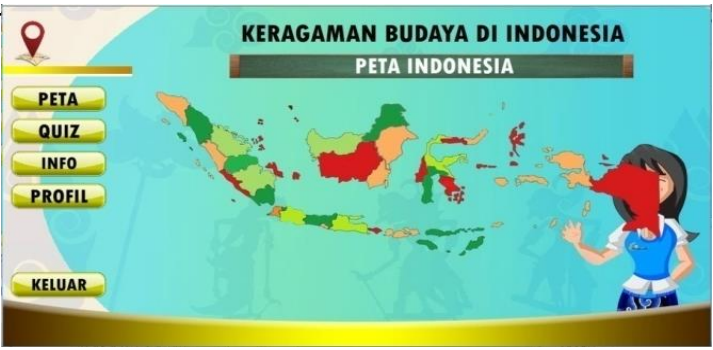

Gambar 2. Tampilan Masuk Menu Utama

Gambar 2 menunjukkan tampilan masuk menu utama Media Pembelajaran Keragaman Budaya Indonesia.

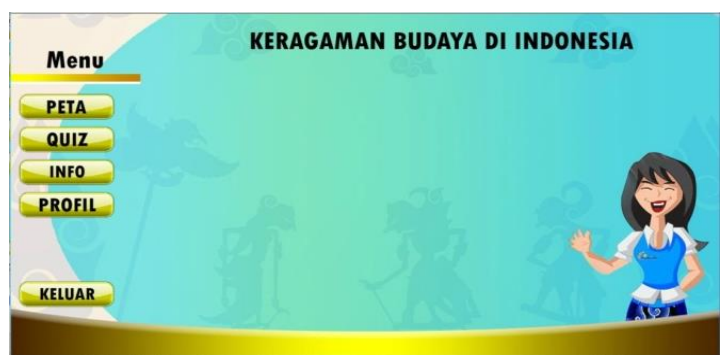

Gambar 3. Tampilan Sub Menu Utama

Gambar 3 menujukkan tampilan sub menu utama Media Pembelajaran Keragaman Budaya Indonesia

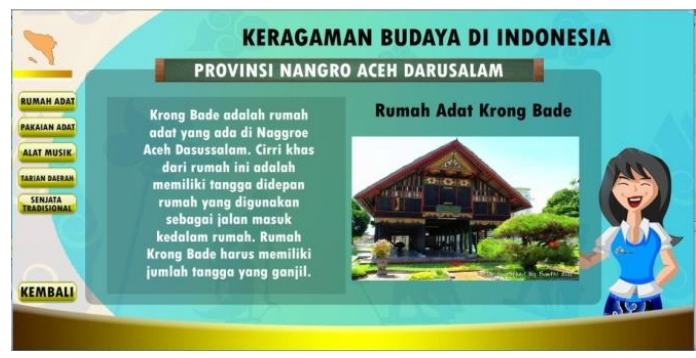

Gambar 4. Tampilan Menu Peta

Gambar 4 menunjukkan Tampilan Menu Peta Indonesia.

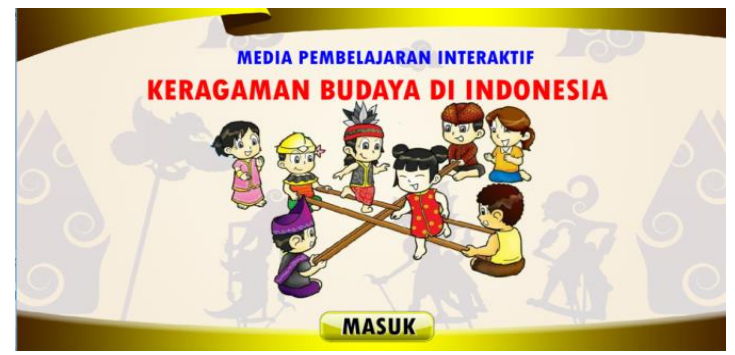

Gambar 5. Tampilan Menu Rumah Adat 
Gambar 5 menunjukkan Tampitan Menu Rumah Adat sesuai daerah yang telah dipilih di menu Peta sebelumnya.

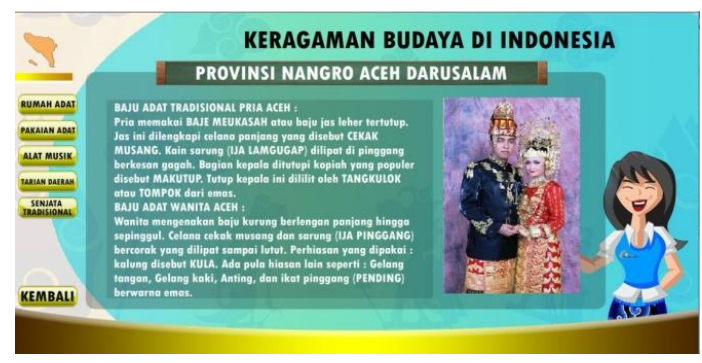

Gambar 6. Tampilan Menu Baju Adat

Gambar 6 menunjukkan Tampilan Menu Baju Adat sesuai daerah yang telah dipilih di menu Peta sebelumnya.

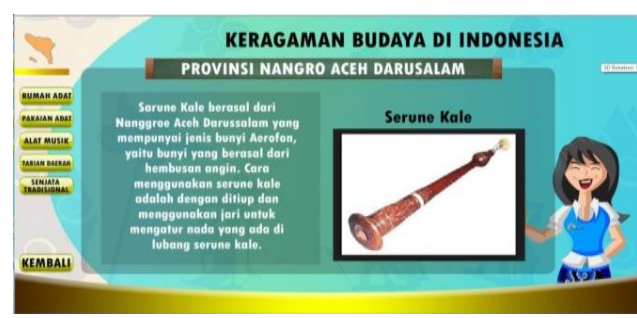

Gambar 7. Tampilan Menu Alat Musik Tradisional

Gambar 7 menunjukkan Tampilan Menu Alat Musik Tradisional sesuai daerah yang telah dipilih di menu Peta sebelumnya.

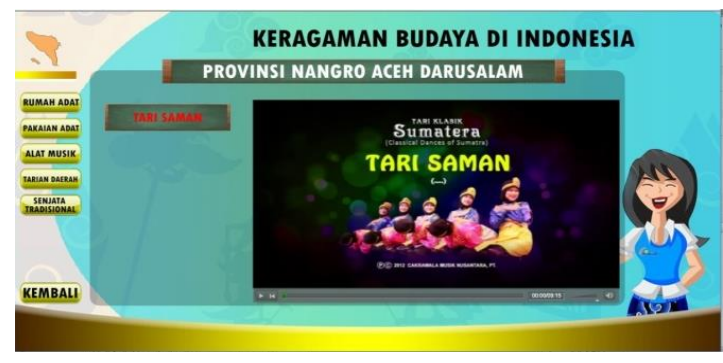

Gambar 8. Tampilan Menu Tari Daerah

Gambar 8 menunjukkan Tampilan Menu Tari Daerah sesuai daerah yang telah dipilih di menu Peta sebelumnya.

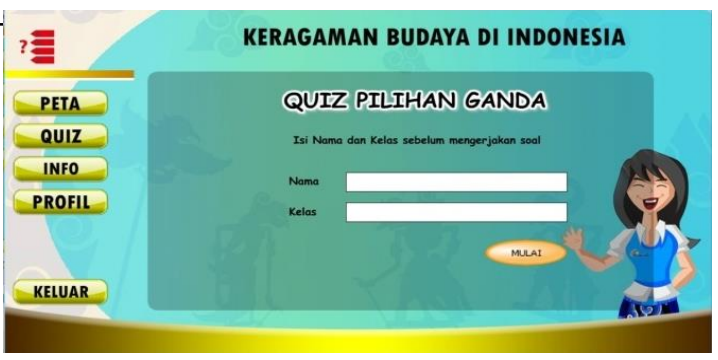

Gambar 9. Tampilan Menu Quiz

Gambar 9 menunjukkan Tampilan Menu Quiz.

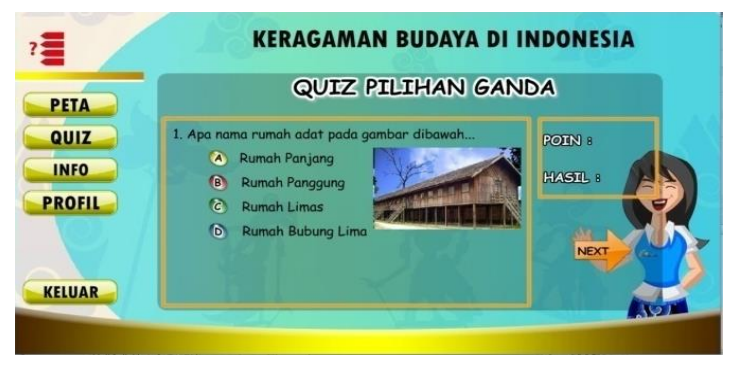

Gambar 10. Tampilan Menu Nilai Quiz

Gambar 10 menunjukkan Tampilan Menu Hasil Quiz.

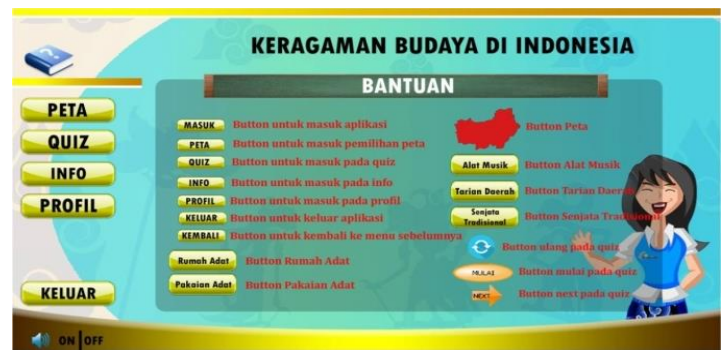

Gambar 11. Tampilan Menu Info Gambar 11 menunjukkan tampilan menu Info yang memuat bantuan.

\section{PEMBAHASAN}

Aplikasi pembelajaran berbasis multimedia ini dibuat semenarik mungkin untuk dapat digunakan dalam proses pembelajaran. Dalam penyajian materi, media pembelajaran ini menampilkan halaman materi yang menarik berupa teks, gambar, video dan audio agar pengguna tidak bosan untuk menggunakannya. 
A. Mewengkang, A. Takaredase, Jurnal Sains dan Teknologi, Universitas Negeri Manado P. Y. Kale'e www.unima.ac.id/lppm/efrontiers

Aplikasi pembetajaran ini dibuat

berdasarkan metode pengembangan MDLC (Multimedia Development Life Cycle) dan penelitian ini dilakukan sampai pada tahap pengujian (Testing). Berdasarkan hasil pengujian menggunakan metode white box dan black box, dapat dilihat bahwa aplikasi pembelajaran ini dapat berfungsi dengan baik, dan peneliti menyimpulkan bahwa media pembelajaran ini layak digunakan pada SDN Lanumor.

\section{PENUTUP}

\section{Kesimpulan}

Berdasarkan hasil penelitian dan pembahasan dapat disimpulkan bahwa pengembangan pembelajaran berbasis multimedia pada mata pelajaran IPS kelas V SDN Lanumor Kabupaten Morowali Utara ini menggunakan metode MDLC (Multimedia Development Life Cycle) yang dilakukan sampai pada tahap testing dan menggunakan white box untuk developer test dan black box untuk end user test. Dengan adanya media pembelajaran untuk anak sekolah dasar ini, kiranya dapat membantu guru dalam proses penyampaian materi dan dapat menjadi sarana belajar bagi siswa. Selain itu media pembelajaran ini layak untuk digunakan setelah melewati pengujian.

\section{Saran \\ 1. Dengan adanya media pembelajaran ini diharapkan dapat menjadi acuan untuk pembuatan media-media pembelajaran baru, dengan menggunakan konsep yang berbeda dan baru. \\ 2. Pembelajaran berbasis multimedia pada mata pelajaran IPS kelas V SDN Lanumor Kabupaten Morowali Utara di}

\section{DAFTAR PUSTAKA}

Arsyad, A. (2011). Media Pembelajaran. Jakarta: Rajawali Pers.

Asmara, I. (2018, Mei 12). Memahami Keragaman Budaya Indonesia dan Masyarakat Multikultura. Dipetik Juli 24, 2018, dari Ibnu Asmara:https://ibnuasmara.com /keragaman-budaya-indonesia.

Hamalik, O. (2006). Proses Belajar Mengajar. Jakarta: PT Bumi Angkasa.

Medcoms. (2012). Kupas Tuntas Adobe Flash Professional CS6. Yogyakarta: Andi Offiset.

Munir. (2009). Pembelajaran Jarak Jauh Berbasis Teknologi Informasi dan Komunikasi. Bandung: Alfabeta.

Sutopo, A. H. (2003). Multimedia Interaktif dan Flash. Yogyakarta: PT Graha Ilmu. 
A. Mewengkang, A. Takaredase, Jurnal Sains dan Teknologi, Universitas Negeri Manado P. Y. Kale'e www.unima.ac.id/lppm/efrontiers

\section{THIS PAGE IS INTENTIONALLY LEFT BLANK}

